\title{
EVALUASI TEKNIK PEMUTIHAN DALAM RESTORASI KERTAS ARSIP
}

\author{
Sari Hasanah \\ Arsip Nasional Republik Indonesia, Jl. Ampera Raya Cilandak Timur, Jakarta Selatan \\ hasanah_sari@yahoo.com
}

Diterima : 16 Juni 2015, Revisi akhir : 9 Oktober 2015, Disetujui terbit : 27 November 2015

\section{EVALUATION OF BLEACHING TECHNIQUE IN RESTORATION OF ARCHIVAL PAPER}

\begin{abstract}
The objective of this research is to study the effects of bleaching on paper archives so the possibilities of bleaching techniques used in the restoration of archives will be known. Experiments were conducted on papers often used as the based material for the archives and archives that have hundreds years old age. Bleaching was done by soaking the solution of potassium permanganate and oxalic acid for fifteen minutes. Control papers and treated papers were analyzed for physical and chemical charasteristics, including physical condition, acid content, tear resistance and folding endurance. The effects of bleaching were known by comparing analysis results of control papers and treated papers. The results showed that the bleaching process on white paper made the color of paper darker, but on brown paper be whiter. Other results showed that bleaching process reduced the physical and chemical properties of paper and risky very much such as losing the letter on the paper, tearing, wrinkling / waving, uneven color and the emergence of new stains. The bleaching technique do not recommended for historical and national interest archives.
\end{abstract}

Keywords: archives, bleaching, historical value, paper, stains

\begin{abstract}
ABSTRAK
Penelitian ini bertujuan untuk mempelajari efek pemutihan pada kertas arsip sehingga akan diketahui kemungkinan penerapan penggunaan teknik pemutihan dalam restorasi arsip. Penelitian dilakukan terhadap kertas yang sering digunakan sebagai bahan dasar arsip dan juga terhadap arsip yang telah berusia ratusan tahun. Pemutihan dilakukan dengan merendam kertas dalam larutan kalium permanganat dan asam oksalat selama lima belas menit. Kertas kontrol dan kertas yang diberi perlakuan pemutihan dianalisis dengan parameter fisik dan kimia meliputi kondisi fisik, kadar asam, ketahanan sobek dan ketahanan lipatnya. Efek dari pemutihan diketahui dari perbandingan hasil analisis terhadap kertas kontrol dengan kertas yang telah dilakukan proses pemutihan. Hasil penelitian menunjukkan bahwa proses pemutihan pada bahan kertas berwarna putih akan mengotori warna kertas dan membuat warna semakin gelap sedangkan proses pemutihan pada bahan kertas yang berwarna coklat akan membuat warna kertas menjadi lebih putih. Hasil lainnya menunjukkan proses pemutihan dapat menurunkan sifat fisika dan kimia kertas dan menimbulkan resiko yang sangat tinggi terhadap kertas yaitu hilangnya tulisan, robeknya kertas, timbulnya kerutan/gelombang, warna yang tidak merata serta timbulnya noda baru. Berdasarkan efek yang ditimbulkan pemutihan, maka kertas arsip yang bernilai kesejarahan dan memiliki kepentingan nasional tidak dianjurkan dilakukan proses pemutihan.
\end{abstract}

Kata kunci: arsip, pemutihan, nilai sejarah, kertas, noda warna 


\section{PENDAHULUAN}

Kertas dapat digambarkan sebagai lembaran dengan komposisi utama serat selulosa sebagai bahan bakunya. Sifat optik kertas menentukan grade dari kertas, khususnya brightness dan whiteness yang merupakan parameter kunci dalam menentukan nilai final dari suatu produk (He Shi dkk., 2012). Selain dengan menggunakan instrumen, sifat optik ini ada yang bisa terlihat secara visual.

Pemutihan dapat memperbaiki sifat optik dari kertas sehingga tampilan kertas berubah. Menurut Smith (2007) dan Smuts (2014), pemutihan adalah tindakan menghilangkan warna atau noda menggunakan bahan kimia atau cahaya sehingga benda menjadi lebih putih atau terang. Zerek (2014) juga menyatakan bahwa pemutihan merupakan suatu prosedur secara kimia (bisa menggunakan sinar) untuk mengubah noda sehingga berkurang warnanya melalui reaksi oksidasi dan reduksi. Berdasarkan definisi ini pemutihan dapat dilakukan dengan dua cara yaitu dengan menggunakan cahaya dan bahan kimia.

Cahaya yang digunakan dalam pemutihan terdiri dari dua macam yaitu cahaya alami dan cahaya buatan. Cahaya alami digunakan untuk pemutihan kertas di abad 18 dan abad 19. Metode ini dapat digunakan untuk beberapa jenis noda dan menggunakan filter ultraviolet. Perlakuan dapat dilakukan dengan dan tanpa air, sedangkan pemutihan menggunakan cahaya buatan bersumber dari GE spectra tubes (40100 watts), sylvania cool light, Norelco daylight; tungsten dan halogen. Selain cahaya, bahan kimia digunakan dalam proses pemutihan. Menurut Zerek (2014), kloramin T dan kalium permanganat merupakan bahan kimia yang sering digunakan dalam pemutihan kertas. Proses pemutihan yang dibahas dalam tulisan ini adalah pemutihan dengan menggunakan bahan kimia kalium permanganat yang merupakan bahan kimia yang mudah diperoleh di pasaran serta harganya murah. Kalium permanganat juga biasa digunakan dalam proses pemutihan buku dan majalah.

Noda merupakan salah satu masalah yang sering ditemui dalam preservasi arsip/dokumen berbahan dasar kertas. Noda dapat diketahui dari area yang berubah warnanya secara kontras. Salah satu cara untuk menghilangkan noda pada kertas dapat dilakukan dengan menggunakan teknik pemutihan kertas, tetapi di Indonesia teknik ini belum pernah diterapkan terhadap arsip. Indonesia merupakan negara yang rawan bencana. Bencana ini seringkali menerpa arsip, misalnya banjir dan kebakaran. Terkait dengan bencana ini, instansi harus membuat rencana untuk melindungi koleksi arsip/dokumen yang dimiliki. Berdasarkan permintaan untuk memperbaiki penampilan fisik arsip berbahan dasar kertas yang terkena noda akibat bencana perlu dilakukan penelitian untuk mengetahui sejauhmana pemutihan bisa diterapkan terhadap arsip. Selama ini proses pemutihan kertas dilakukan terhadap karya cetak seperti buku dan majalah. Arsip berbeda dengan buku atau majalah yang dapat digandakan dalam jumlah tak terhingga. Arsip yang bernilai kesejarahan dan memiliki kepentingan nasional disimpan di lembaga kearsipan dalam bentuk asli dan bukan merupakan hasil fotokopi. Arsip ini merupakan rekaman hasil kegiatan atau peristiwa yang dibuat dan diterima lembaga dan perseorangan dalam rangka pelaksanaan kehidupan bermasyarakat, berbangsa, dan bernegara.

Kegiatan preservasi arsip dilakukan agar arsip bisa bertahan hingga masa yang akan datang. Pasal 63 ayat (1) dan (2) Undang-undang Nomor 43 Tahun 2009 Tentang Kearsipan menyebutkan bahwa preservasi arsip statis dilakukan untuk menjamin keselamatan dan kelestarian arsip statis serta dilakukan secara preventif dan kuratif. Salah satu tindakan kuratif adalah restorasi/ perbaikan terhadap arsip yang rusak. Tulisan ini menggambarkan kemungkinan penerapan teknik pemutihan terhadap arsip-arsip yang memerlukan perbaikan/restorasi.

Menurut Zevros dkk. (2015), metode yang digunakan dalam preservasikertas diklasifikasikan menjadi tujuh kategori yaitu persiapan intervensi, sterilisasi, pembersihan basah, pembersihan kering, stabilisasi kimia, perbaikan kertas, dan penguatan kertas. Pemutihan masuk dalam kategori pembersihan basah. Teknik lainnya yang masuk ke dalam kategori pembersihan basah adalah pencucian menggunakan air/pelarut organik dan perlakuan enzim.

Restorasi kertas dapat dilakukan dengan teknik pemutihan (Hofmann dkk., 1991; Nakagoshi dan Yoshizumi, 2011). Penelitian mengenai efek pemutihan terhadap kertas arsip belum pernah dilakukan di Indonesia. Oleh karena itu, tujuan 
dari penelitian ini adalah untuk mengetahui efek dari pemutihan pada kertas arsip sehingga informasi yang diperoleh dari penelitian ini dapat berguna bagi kegiatan restorasi arsip.

\section{BAHAN DAN METODE}

\section{Bahan}

Bahan yang digunakan pada penelitian ini adalah kertas kosong yang belum digunakan dan diperoleh di pasaran yaitu kertas HVS dengan gramatur $100 \mathrm{~g} / \mathrm{m}^{2}, 80 \mathrm{~g} / \mathrm{m}^{2}, 70 \mathrm{~g} / \mathrm{m}^{2}$ serta kertas conqueror dengan gramatur $100 \mathrm{~g} / \mathrm{m}^{2}$. Selain kertas kosong juga digunakan kertas arsip yang berusia ratusan tahun. Bahan kimia yang digunakan adalah bahan kimia pro analysis (p.a) yaitu kalium permanganat, $1 \%$ asam oksalat, dan 3\% magnesium karbonat serta gas karbon dioksida. Larutan deasidifikasi dibuat dengan mengalirkan gas karbon dioksida selama satu jam ke dalam larutan magnesium karbonat $2 \%$. Peralatan yang digunakan adalah alat uji ketahanan lipat MIT, alat uji ketahanan sobek Elmendorf, $\mathrm{pH}$ meter, tabung gas, kipas angin, peralatan gelas, bak perendam, dan streaming sebagai alas kertas.

\section{Metode}

Masing-masing contoh kertas dibagi dalam dua bagian. Satu bagian tidak diberi perlakuan sebagai kontrol dan satu bagian diberi perlakuan. Perlakuan meliputi perendaman dalam larutan pemutih dan deasidifikasi. Sebelum perlakuan, kertas direndam di dalam bak yang berisi air selama satu menit (Smith, 2007). Setelah perendaman dengan air, perlakuan terhadap kertas secara berturut-turut, yaitu: perendaman dalam larutan kalium permanganat 1\% selama lima belas menit; dalam larutan asam oksalat 3\% lima belas menit; dalam air selama satu jam dan dalam larutan deasidifikasi selama 1 jam. Setelah perendaman selesai, kertas dikeringkan dengan bantuan kipas angin selama 24 jam. Analisis yang dilakukan meliputi: pengamatan kondisi fisik kertas (bentuk dan warna secara visual); tingkat keasaman $(\mathrm{pH})$ mengacu pada SNI ISO 6588-1:2010; ketahanan sobek mengacu pada SNI 0436:2009; ketahanan lipat mengacu pada SNI 0491:2009.

\section{HASIL DAN PEMBAHASAN}

\section{Kondisi Fisik Kertas Hasil Pemutihan}

Hasil pengamatan warna fisik kertas setelah dilakukan pemutihan dapat dilihat pada Tabel 1 .

Tabel 1. Pengamatan Warna Fisik Kertas

\begin{tabular}{|c|c|c|c|}
\hline No & Contoh & $\begin{array}{l}\text { Warna } \\
\text { Awal }\end{array}$ & $\begin{array}{c}\text { Warna } \\
\text { Hasil } \\
\text { Pemutihan }\end{array}$ \\
\hline 1 & Conqueror $100 \mathrm{~g} / \mathrm{m}^{2}$ & Putih Krem & Krem \\
\hline 2 & HVS $100 \mathrm{~g} / \mathrm{m}^{2}$ & Putih & Krem \\
\hline 3 & HVS $80 \mathrm{~g} / \mathrm{m}^{2}$ & Putih & Krem \\
\hline 4 & HVS $70 \mathrm{~g} / \mathrm{m}^{2}$ & Putih & Krem \\
\hline 5 & Arsip 1 (th 1721) & Coklat & Putih \\
\hline 6 & Arsip 2 (th 1855) & Coklat & Putih \\
\hline
\end{tabular}

Pada Gambar 1, 2, 3 dan 4 yaitu kertas conqueror $100 \mathrm{~g} / \mathrm{m}^{2}$, HVS $100 \mathrm{~g} / \mathrm{m}^{2}$, HVS $80 \mathrm{~g} / \mathrm{m}^{2}$, HVS $70 \mathrm{~g} / \mathrm{m}^{2}$ awal dan hasil pemutihan dapat dilihat bahwa warna kertas hasil pemutihan tidak lebih putih dibandingkan kertas awal karena larutan bahan kimia pemutih yang digunakan (kalium permanganat 1\%) merupakan larutan berwarna ungu tua sehingga menyebabkan warna putih dari kertas menjadi lebih buram/gelap. Pemutihan pada bahan kertas yang secara visual masih berwarna putih tidak perlu dilakukan karena hanya akan menyebabkan perubahan warna menjadi lebih gelap. Menurut Hubbe dkk. (2008), penampilan kertas dipengaruhi oleh keberadaan kotoran, tinta, dan pembentukan uniformity.

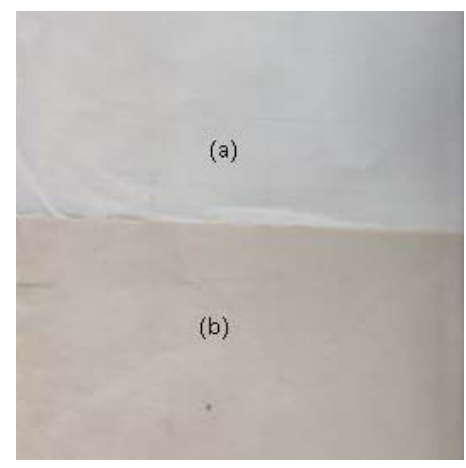

Gambar 1. Kertas Conqueror $100 \mathrm{~g} / \mathrm{m}^{2}$, (a) awal dan (b) hasil pemutihan 


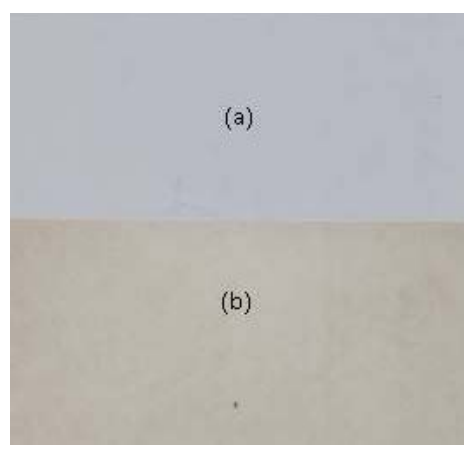

Gambar 2. Kertas HVS $100 \mathrm{~g} / \mathrm{m}^{2}$, (a) awal dan (b) hasil pemutihan

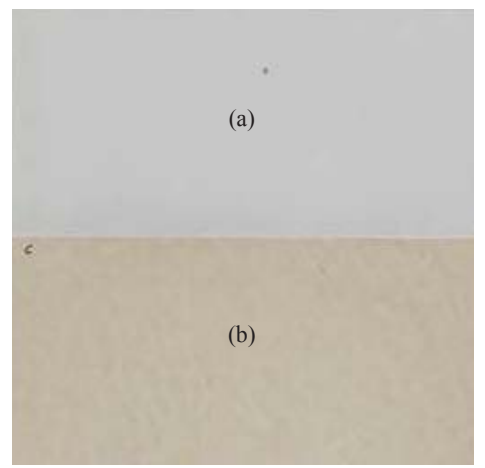

Gambar 3. Kertas HVS $80 \mathrm{~g} / \mathrm{m}^{2}$, (a) awal dan (b) hasil pemutihan

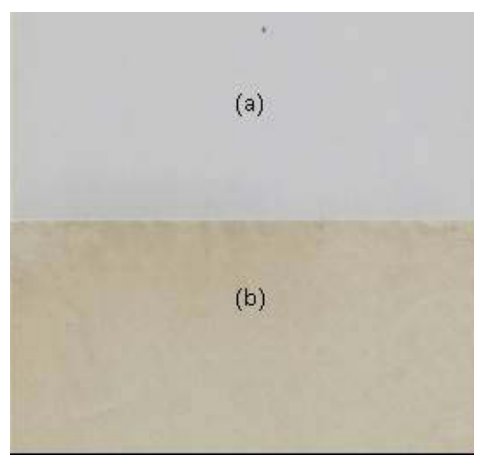

Gambar 4. Kertas HVS 70 g/m², (a) awal dan (b) hasil pemutihan

Menurut James dkk. (1997), kertas yang diberi perlakuan dengan larutan permanganat akan berubah menjadi coklat karena adanya mangan dioksida. Sebelumnya, kertas ini berwarna ungu hanya dalam waktu singkat tetapi kemudian berubah menjadi coklat. $\mathrm{pH}$ sangat mempengaruhi reaksi yang terjadi. Diketahui bahwa proses pemutihan diakhiri dengan proses deasidifikasi dan pembilasan yang memungkinkan perubahan $\mathrm{pH}$ menjadi netral. Menurut Ahluwalia (2005), dalam suasana netral kalium permanganat akan menghasilkan mangan dioksida. Reaksi yang terjadi adalah :

$\mathrm{MnO}_{4}^{-}(\mathrm{aq})+2 \mathrm{H}_{2} \mathrm{O}(\mathrm{l})+3 \mathrm{e}^{-} \leftrightarrow \mathrm{MnO}_{2}(\mathrm{~s})+4 \mathrm{OH}^{-}(\mathrm{aq})$

Menurut Hubbe dkk. (2008), banyak faktor yang mempengaruhi tampilan kertas yaitu fungsi dari struktur detilnya, keberadaan dan konsentrasi gugus yang menyerap cahaya (kromofor), indeks refraksi komponen, berat, dan karakteristik pantulan permukaan. Hasil pemutihan pada kertas arsip dapat dilihat pada Gambar 5 dan 6.

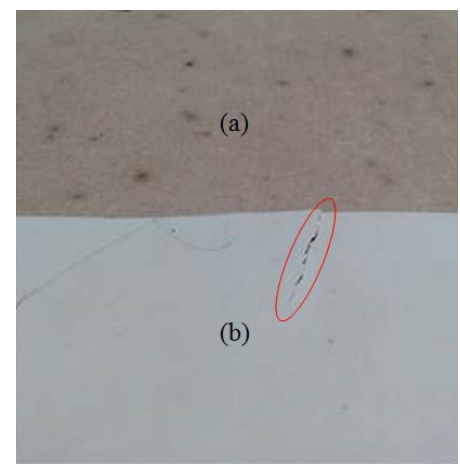

Gambar 5. Kertas Arsip tahun 1721,

(a) awal dan (b) hasil pemutihan

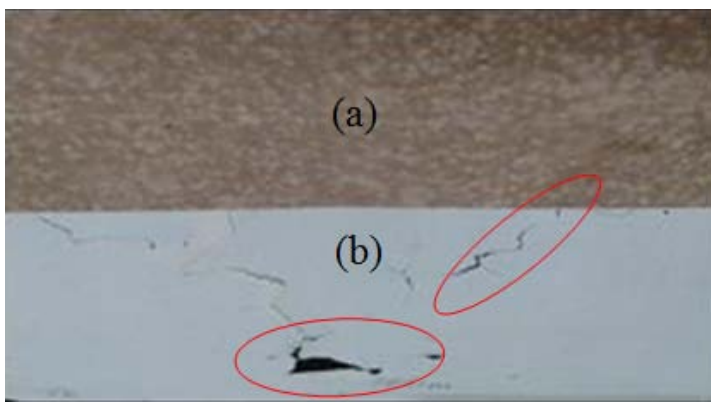

Gambar 6. Kertas Arsip tahun 1855,

(a) awal dan (b) hasil pemutihan

Dari Gambar 5 dan 6 dapat dilihat kertas hasil pemutihan lebih putih dibandingkan kertas awal, proses pemutihan memperbaiki penampilan fisik kertas. Kertas arsip yang dijadikan contoh adalah kertas arsip tahun 1721 yang telah berusia hampir 300 tahun. Proses pemutihan, selain memperbaiki warna kertas arsip menjadi putih, juga menyebabkan pudarnya noda-noda hitam yang ada, sehingga penampilan kertas arsip menjadi lebih baik. Menurut Smuts (2014), hal tersebut disebabkan oleh perubahan struktur molekul selulosa dan putusnya ikatan gugus warna kromofor 
Dalam penelitian ini, bahan kimia yang digunakan adalah kalium permanganat dan asam oksalat. Kalium permanganat $\left(\mathrm{KMnO}_{4}\right)$ adalah oksidator kuat. Adapun asam oksalat atau asam etanadioat $\left(\mathrm{H}_{2} \mathrm{C}_{2} \mathrm{O}_{4}\right)$ merupakan asam organik yang relatif kuat, 10.000 kali lebih kuat daripada asam asetat. Anionnya yang dikenal sebagai oksalat merupakan agen pereduktor. Reaksi yang terjadi antara kalium permanganat dan asam oksalat adalah sebagai berikut (Ahluwalia, 2005):

$$
\begin{gathered}
2 \mathrm{MnO}_{4}^{-}(\mathrm{aq})+16 \mathrm{H}+(\mathrm{aq})+5 \mathrm{C}_{2} \mathrm{O}_{4}^{2-}(\mathrm{aq}) \leftrightarrow \\
2 \mathrm{Mn}_{2}+(\mathrm{aq})+10 \mathrm{CO}_{2}(\mathrm{~g})+8 \mathrm{H}_{2} \mathrm{O}(\mathrm{l})
\end{gathered}
$$

Pewarnaan merupakan masalah yang sering ditemui dalam preservasi arsip. Noda warna merupakan area yang telah berubah warnanya secara kontras. Serat alam merupakan bahan yang mudah menyerap zat lain. Menurut Department of Art Conservation of Bishop Museum (1996), pemutihan tidak menghilangkan noda warna namun hanya mengubah warna noda menjadi berkurang wamañya atau tidak terlihat. Beberapa struktur molekul atau fenomena fisik menyebabkan serat menjadi lebih berwarna atau menjadi gelap. Struktur molekul yang bersifat tidak jenuh (ikatan rangkap) seperti fenol dan karbonil, menggeser penyerapan cahaya dari rentang ultraviolet atau UV menjadi rentang sinar tampak. Dengan memotong sistem ikatan rangkap, senyawa berwarna menjadi berkurang warnanya, sehingga noda warna menjadi tidak terlihat. Hal ini dapat dilakukan dengan memecah atau membuat jenuh ikatan rangkap. Golongan karbonil dapat direduksi menjadi alkohol atau dioksidasi menjadi asam karboksilat, keduanya senyawa yang kurang berwarna. Oksidasi seringkali menyebabkan hilangnya warna asal karena adanya sistem unconjugated dan juga menyebabkan sistem yang tidak stabil.

Jika dibandingkan dengan bahan pemutih lainnya seperti natrium borohidrat, kalsium hipoklorit, hidrogen peroksida, pemutihan menggunakan kalium permanganat menunjukkan tingkat kestabilan warna yang paling rendah setelah dilakukan aging (Hofmann dkk, 1991). Setelah dilakukan aging, timbul bercak noda hitam yang mungkin merupakan residu mangan. Dengan adanya noda tersebut menunjukkan bahwa pemutihan menimbulkan resiko timbulnya noda selanjutnya. Menurut Department of Art Conservation of Bishop Museum (1996), pemutihan dapat menyebabkan sistem menjadi tidak stabil, memicu reaksi selanjutnya yang menghasilkan senyawa berwarna lagi, hal ini disebut reversion.

Efek lainnya dari proses pemutihan adalah sobeknya kertas dan terjadinya lubang (tanda merah pada Gambar 5 dan 6). Hal ini karena kertas sudah tua dan rapuh. Arsip-arsip yang disimpan lama bersifat rapuh walaupun penampilan fisiknya terlihat lebih kuat sehingga mudah sobek jika mengalami sedikit tekanan. Sobek dan berlubangnya kertas arsip akibat pemutihan sangat membahayakan kertas arsip karena dapat menghilangkan informasi penting yang terkandung di dalamnya.

Efek berikutnya dari proses pemutihan adalah tidak meratanya warna hasil pemutihan, yaitu ada bagian-bagian tertentu yang lebih gelap dari daerah sekitarnya (Gambar 7) atau adanya bercak yang lebih putih di area sekitarnya (Gambar 8) dan timbulnya kerutan-kerutan. Proses ini dilakukan menggunakan streaming atau alas dan dilakukan perendaman lembar demi lembar dan satu persatu, namun resiko tidak meratanya warna putih tetap ada.

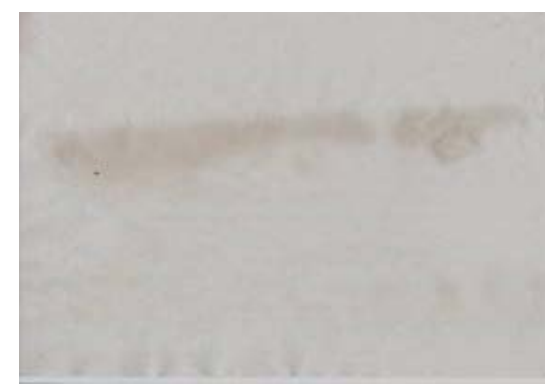

Gambar 7. Pewarnaan yang tidak merata pada kertas hasil pemutihan

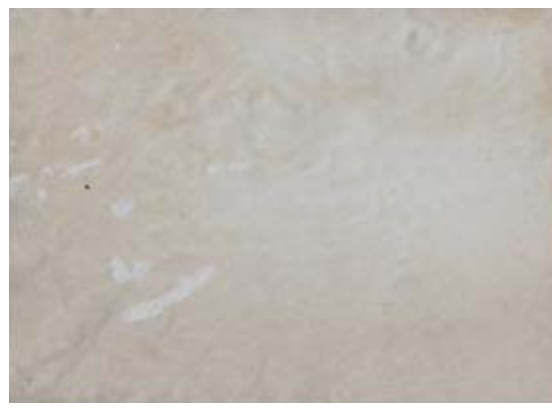

Gambar 8. Bercak-bercak putih pada kertas hasil pemutihan

Efek negatif pemutihan pada Gambar 7 dan 8 disebabkan oleh proses perendaman yang tidak sempurna dan proses pengeringan yang 
tidak maksimal. Efek negatif ini perlu menjadi pertimbangan dalam melakukan preservasi kertas arsip. Kertas yang memiliki nilai kesejarahan tidak bisa dilakukan pemutihan karena dapat menghilangkan nilai yang terkandung dalam kertas sehingga tidak autentik lagi. Beberapa noda memiliki nilai sejarah dan seharusnya tidak dihilangkan. Dalam berbagai kasus, noda bisa saja sangat menganggu karena begitu banyak dan sangat gelap. Namun jika noda ini dihilangkan maka bisa menghapuskan desain penting fitur yang digunakan untuk menafsirkan suatu bahan bersejarah secara benar. Biasanya kertas yang menguning diabaikan karena menandakan tandatanda zaman dan akibat penggunaan. Nilai sejarah yang terkandung juga merupakan pertimbangan utama dalam memperbaiki arsip/dokumen bersejarah seperti yang pernah dilakukan lembaga arsip kanada. Original copy teks Proclamation of the Constitution Act, 1982 terkena tumpahan zat warna merah akibat kelalaian manusia. Teks proklamasi ini akhirnya tidak dilakukan perbaikan walaupun ada wacana untuk memperbaikinya kembali dengan penggunaan bahan kimia yang lain. Akhirnya noda ini dibiarkan saja demi memperhatikan originalitas dan autentikasi arsip proklamasi tersebut (Whalen, 2006).

Ukuran, lokasi, dan tingkat kegelapan noda menjadi bahan pertimbangan sebelum pemutihan dilakukan. Jika dengan dilakukan pemutihan akan menyebabkan warna yang tidak merata, maka pemutihan tidak dilakukan.

Jenis dari noda akan membantu dalam menentukan apakah pemutihan akan menjadi efektif. Noda yang fresh/baru dengan penetrasi sangat kecil ke dalam serat biasanya akan sukses hilang melalui metode pencucian tanpa harus pemutihan. Department of Art Conservation of Bishop Museum (1996) menyatakan bahwa noda yang telah ada di serat lebih dari 3 bulan biasanya dianggap sudah menyatu, terikat atau bereaksi dengan serat sehingga sulit dilepas.

\section{pH Kertas Hasil Pemutihan}

Dalam penelitian ini dilakukan pengukuran $\mathrm{pH}$ dengan tujuan untuk mengetahui apakah kertas hasil pemutihan menjadi bersifat asam atau tidak. $\mathrm{pH}$ merupakan parameter yang penting dalam permanensi kertas dan dipersyaratkan dalam archival paper sesuai ISO 11108:1996 Information And Documentation, Archival Paper, Requirements For Permanence And Durability. Kandungan asam di dalam kertas dapat mempercepat reaksi hidrolisis sehingga mempercepat kerusakan kertas. Hidrolisis merupakan suatu reaksi yang terjadi karena adanya air. Reaksi tersebut menyebabkan putusnya rantai polimer serat selulosa membentuk unit-unit yang lebih kecil dan molekul air. Sifat asam dapat dengan mudah berpindah jika terjadi kontak langsung antara arsip yang bersifat asam.

Perubahan $\mathrm{pH}$ kertas awal dan hasil pemutihan dapat dilihat pada Tabel 2. $\mathrm{pH}$ kertas awal berkisar antara 8,68-9,20 sedangkan $\mathrm{pH}$ kertas hasil pemutihan berkisar 8,19-8,55. Data ini menunjukkan bahwa terjadi penurunan $\mathrm{pH}$ dan ratarata penurunannya tidak melebihi satu skala $\mathrm{pH}$. Penurunan $\mathrm{pH}$ disebabkan oleh penggunaan asam oksalat pada proses pemutihan. Kelebihan asam dari asam oksalat diatasi dengan melakukan proses deasidifikasi pada teknik pemutihan ini, sehingga kertas kembali bersifat basa $(\mathrm{pH}$ kertas hasil pemutihan bersifat basa pada kisaran 8,19-8,55). Selain deasidifikasi, proses pencucian/pembilasan menggunakan air suling yang dilakukan juga memegang peranan dalam mempengaruhi $\mathrm{pH}$. Menurut Hofmann dkk. (1991), proses pencucian

Tabel 2. Perubahan pH Kertas Awal dan Hasil Pemutihan

\begin{tabular}{clccc}
\hline No & \multicolumn{1}{c}{ Contoh } & pH Awal & pH Hasil Pemutihan & $\begin{array}{c}\text { Penurunan } \\
\mathrm{pH}\end{array}$ \\
\hline 1 & Conqueror $100 \mathrm{~g} / \mathrm{m}^{2}$ & $9,14 \pm 0,19$ & $8,52 \pm 0,04$ & 0,62 \\
2 & HVS $100 \mathrm{~g} / \mathrm{m}^{2}$ & $9,20 \pm 0,04$ & $8,19 \pm 0,07$ & 1,01 \\
3 & HVS $80 \mathrm{~g} / \mathrm{m}^{2}$ & $8,68 \pm 0,48$ & $8,55 \pm 0,12$ & 0,13 \\
4 & HVS 70 g/m & $8,76 \pm 0,04$ & $8,22 \pm 0,08$ & 0,54 \\
\hline
\end{tabular}


dan deasidifikasi dapat memperbaiki $\mathrm{pH}$ kertas yang telah mengalami pemutihan. Selain menetralkan asam pada kertas hasil pemutihan, proses deasidifikasi juga memberi bahan penahan (buffer) pada kertas untuk melindungi kertas dari pengaruh asam dari luar.

\section{Ketahanan Sobek Hasil Pemutihan}

Ketahanan sobek merupakan parameter yang penting dalam permanensi kertas dam merupakan salah satu parameter yang dipersyaratkan dalam kertas arsip sesuai ISO 11108:1996 Information And Documentation, Archival Paper, Requirements For Permanence And Durability. Nilai ketahanan sobek kertas hasil pemutihan dapat dilihat pada Tabel 3 .

Berdasarkan Tabel 3 dapat dilihat bahwa kekuatan fisik kertas yaitu ketahanan sobek mengalami penurunan setelah dilakukan proses pemutihan. Penurunan kekuatan berdasarkan hasil pengukuran ini beragam yaitu 23,2 - 37,7\% dari kekuatan awal. Hal ini terjadi pada semua jenis kertas yang diuji baik dari gramatur yang tertinggi yaitu $100 \mathrm{~g} / \mathrm{m}^{2}$ hingga gramatur $70 \mathrm{~g} / \mathrm{m}^{2}$. Berdasarkan hasil ini dapat diketahui bahwa proses pemutihan akan menyebabkan penurunan kualitas kekuatan kertas dalam hal ini kekuatan sobek. Menurut Elyani (2006), faktor-faktor yang mempengaruhi ketahanan sobek adalah panjang serat, jumlah ikatan serat, jumlah total serat yang berperan dalam penyobekan, bahan pengisi dan fleksibilitas serat. Dinding serat yang tebal akan mempunyai ketahanan sobek yang tinggi dibandingkan dengan serat yang memiliki dinding tipis. Serat selulosa pada kertas dapat mengalami kerusakan akibat proses oksidasi, asam, basa, dan paparan cahaya baik matahari atau buatan.

\section{Ketahanan Lipat Hasil Pemutihan}

Ketahanan lipat merupakan parameter yang penting dalam durabilitas kertas dan merupakan salah satu parameter yang dipersyaratkan dalam kertas arsip sesuai ISO 11108:1996 Information And Documentation, Archival Paper, Requirements For Permanence And Durability. Pada Tabel 4 dapat dilihat bahwa ketahanan lipat mengalami penurunan setelah dilakukan proses pemutihan. Penurunan ketahanan lipat berbagai contoh kertas berdasarkan hasil pengukuran ini beragam yaitu dari $28,5-84 \%$ dari kekuatan awal. Berdasarkan hasil ini dapat diketahui bahwa proses pemutihan dapat menyebabkan penurunan kualitas kekuatan kertas dalam hal ini kekuatan lipat. Bruckle (2009) dalam Smuts (2014) menyatakan bahwa pemutihan secara potensial dapat merusak media kertas yang menyebabkan perubahan struktur molekul dari berbagai komponen dalam kertas.

Efek negatif proses pemutihan perlu menjadi pertimbangan para ahli preservasi sebelum melakukan pemutihan, dengan memperhatikan kekuatan kertas, nilai sejarah, dan noda dalam kertas. Kekuatan kertas harus dipertimbangkan sebelum mengambil keputusan tindakan pemutihan. Kertas yang rapuh tidak bisa dilakukan pemutihan karena akan menambah kerusakan pada kertas.

Tabel 3. Ketahanan Sobek Kertas Awal dan Hasil Pemutihan

\begin{tabular}{|c|c|c|c|c|}
\hline \multirow{2}{*}{ No } & \multirow{2}{*}{ Contoh } & \multicolumn{2}{|c|}{ Ketahanan Sobek (mN) } & \multirow{2}{*}{ Penurunan $(\%)$} \\
\hline & & Awal & Hasil Pemutihan & \\
\hline 1 & Conqueror $100 \mathrm{~g} / \mathrm{m}^{2}$ & $\begin{array}{l}\mathrm{AM}=1000 \pm 0 \\
\mathrm{SM}=1013 \pm 5,77\end{array}$ & $\begin{array}{l}\mathrm{AM}=704 \pm 5,48 \\
\mathrm{SM}=752 \pm 13,04\end{array}$ & $\begin{array}{l}\mathrm{AM}=29,6 \\
\mathrm{SM}=25,8\end{array}$ \\
\hline 2 & HVS $100 \mathrm{~g} / \mathrm{m}^{2}$ & $\begin{array}{l}\mathrm{AAM}=680 \pm 14,14 \\
\mathrm{SM}=760 \pm 0\end{array}$ & $\begin{array}{l}\mathrm{AM}=424 \pm 8,94 \\
\mathrm{SM}=506 \pm 11,54\end{array}$ & $\begin{array}{l}\mathrm{AM}=37,7 \\
\mathrm{SM}=33,4\end{array}$ \\
\hline 3 & HVS $80 \mathrm{~g} / \mathrm{m}^{2}$ & $\begin{array}{l}\mathrm{AM}=693 \pm 5,77 \\
\mathrm{SM}=700 \pm 21,21\end{array}$ & $\begin{array}{l}\mathrm{AM}=464 \pm 15,16 \\
\mathrm{SM}=493 \pm 5,16\end{array}$ & $\begin{array}{l}\mathrm{AM}=33,0 \\
\mathrm{SM}=29,6\end{array}$ \\
\hline 4 & HVS $70 \mathrm{~g} / \mathrm{m}^{2}$ & $\begin{array}{l}\mathrm{AM}=560 \pm 0 \\
\mathrm{SM}=720 \pm 10\end{array}$ & $\begin{array}{l}\mathrm{AM}=430 \pm 7,07 \\
\mathrm{SM}=480 \pm 11,55\end{array}$ & $\begin{array}{l}\mathrm{AM}=23,2 \\
\mathrm{SM}=33,3\end{array}$ \\
\hline
\end{tabular}


Tabel 4. Ketahanan Lipat Kertas Awal dan Hasil Pemutihan

\begin{tabular}{|c|c|c|c|c|}
\hline \multirow{2}{*}{ No } & \multirow{2}{*}{ Contoh } & \multicolumn{2}{|c|}{ Ketahanan Lipat } & \multirow{2}{*}{$\begin{array}{c}\text { Penurunan } \\
(\%)\end{array}$} \\
\hline & & Awal & Hasil Pemutihan & \\
\hline 1 & Conqueror $100 \mathrm{~g} / \mathrm{m}^{2}$ & $\begin{array}{l}\mathrm{AM}=48 \pm 0,89 \\
\mathrm{SM}=35 \pm 5,47\end{array}$ & $\begin{array}{l}\mathrm{AM}=11 \pm 0,95 \\
\mathrm{SM}=10 \pm 0,45\end{array}$ & $\begin{array}{l}\mathrm{AM}=77,0 \\
\mathrm{SM}=71,0\end{array}$ \\
\hline 2 & HVS $100 \mathrm{~g} / \mathrm{m}^{2}$ & $\begin{array}{l}\mathrm{AM}=33 \pm 4,58 \\
\mathrm{SM}=17 \pm 0,81\end{array}$ & $\begin{array}{l}\mathrm{AM}=5 \pm 0,53 \\
\mathrm{SM}=7 \pm 1,9\end{array}$ & $\begin{array}{l}\mathrm{AM}=84,0 \\
\mathrm{SM}=58,8\end{array}$ \\
\hline 3 & HVS $80 \mathrm{~g} / \mathrm{m}^{2}$ & $\begin{array}{l}\mathrm{AM}=25 \pm 1,50 \\
\mathrm{SM}=17 \pm 0,70\end{array}$ & $\begin{array}{l}\mathrm{AM}=11 \pm 0,96 \\
\mathrm{SM}=6 \pm 0,89\end{array}$ & $\begin{array}{l}\mathrm{AM}=56,0 \\
\mathrm{SM}=64,7\end{array}$ \\
\hline 4 & HVS $70 \mathrm{~g} / \mathrm{m}^{2}$ & $\begin{array}{l}\mathrm{AM}=24 \pm 2,00 \\
\mathrm{SM}=7 \pm 0,00\end{array}$ & $\begin{array}{l}\mathrm{AM}=9 \pm 0,83 \\
\mathrm{SM}=5 \pm 0,44\end{array}$ & $\begin{array}{l}\mathrm{AM}=62,5 \\
\mathrm{SM}=28,5\end{array}$ \\
\hline
\end{tabular}

\section{KESIMPULAN}

Pemutihan pada bahan kertas yang secara visual berwarna putih akan mengotori dan membuat warna semakin gelap sedangkan pada bahan kertas yang berwarna coklat akan membuat warna kertas menjadi lebih putih. Proses pemutihan dapat menurunkan sifat fisika dan kimia kertas serta beresiko tinggi menghilangkan tulisan pada kertas, merobek kertas, menimbulkan kerutan/gelombang, membuat warna kertas tidak merata serta menimbulkan noda baru. Kertas arsip yang bernilai kesejarahan dan memiliki kepentingan nasional tidak dianjurkan direstorasi menggunakan teknik pemutihan.

\section{UCAPAN TERIMA KASIH}

Ucapan terima kasih ditujukan kepada pimpinan dan rekan di ANRI yang telah membantu penulis sehingga dapat menyelesaikan penelitian ini, khususnya kepada Ibu Yanah, Pak Isro, Roby, Sugiyo. Selain itu terima kasih juga ditujukan kepada Bapak Cecep dan Aris yang turut mendukung penelitian ini.

\section{DAFTAR PUSTAKA}

Ahluwalia, V K, Dhingra, S., Gulati, A., 2005. College Practical Chemistry. Universities Press, Hyderguda.

Department of Art Conservation of Bishop Museum, 1996. To Bleach or Not To Bleach. The State Museum of Natural and Cultural History, Honolulu Hawai'i.
Bruckle, I., 2009. Bleaching in Paper Conservation: Decision Making Parameters, The Restaurator. Vol. 30 (4), 321 - 332.

Elyani, N., Sari, F.D., 2006. Penggunaan Rosin Katioik-PAC Untuk Pendarihan pada $\mathrm{pH}$ Netral. Berita Selulosa. Vol. 41 (1), 8-13.

He Shi, Liu, H., Ni, Y., Yuan Z., Zou, X., Zhou, Y., 2012. Review: Use of Optical Brightening Agents (OBAs) in the Production of Paper Containing High-Yield Pulps. BioResources. Vol 7 (2), 2582-2591.

Hofmann, C., Reyden, D.V.D, Baker M., 1991. Comparison and Evaluation of Bleaching Procedures: the Effect of Five Bleaching Methods on the Optical and Mechanical Properties of New and Aged Cotton Linter Paper Before and After Accelerated Aging, The Book and Paper Group ANNUAL. Volume 10. The American Institute for Conservation.

Hubbe, M.A, Pawlak, J.J., Koukoulas A.A., 2008. Paper's Appeareance : A Review. BioResources. 3(2), 627-665.

James, C., Corrigan, C., Christine, M., Marie, E., 1997. Old Master Prints and Drawing. A Guide to Preservation and Conservation, 269-270. Amsterdam University Press, Amsterdam.

Nakagoshi K., Yoshizumi K., 2011. Photobleaching Characteristics of Traditional Japanese Paper in Museum Environment. Natural Science. Vol 3 (11), 948-954.

Smith, T., 2007. Historical Bleaching of Ingres Drawings at the Fogg Art Museum. Smith. The 2007 Annual Student Conference hosted by the Harvard University Art Museums Straus Center for Conservation and Technical Studies, Cambridge. 
Smuts, S., 2014. Diagnosis and Decision Making for Current Oxidative and Reductive Bleaching Treatments Used on Paper. CeROArt.Vol 9.

Whalen, J.M., 2006. Notes And Communications "Out, Damned Spot!" The Staining of The Proclamation of The Constitution Act, 1982. Archivaria The Journal of The Association of Canadian Archivists. Number 6, 289-298.
Zerek, B.F, 2014. The Preservation and Protection of Library Collections A Practical Guide to Microbiological Controls, 418. Chandos Publishing, Oxford.

Zevros, S., Alexopoulu, I., 2015. Paper Conservation Methods: A Literature Review. Cellulose. Vol 22 (5), 2859-2897. 
Lurnal Selulosa, Vol. 4, No. 2, Desember 2015:89- 98 